\title{
The Forgotten
}

\section{VII-A Family}

FROM A SPECIAL CORRESPONDENT

Mr. and Mrs. M. N. were married a quarter of a century ago and have spent all their working life together in the same village; he is an agricultural worker and she works in the village shop. They have never in the whole of their married life slept away from their cottage, because their only child, now 23 , is mentally defective. He must be taken to the lavatory, dressed and undressed, bathed, and exercised. He can say a few words but cannot form sentences, and spends his time playing in a very limited way with his collection of toy buses and trains.

When he was 6 months old $\mathrm{X}$ had a few minor fits, which were thought to be associated with teething. At 9 months his mother began to be anxious because he could not sit up unaided, and when he had a series of fits within a short time specialist assessment was advised; Mrs. M. N. was told that the baby was "very, very backward," and he was given phenobarbitone to control his fits. The couple talked it over and decided that they must subordinate their own interests to that of their son and build their lives around him.

There were no more children, though this was not a deliberate decision, and they settled into the mode of existence that they have followed ever since. $\mathrm{X}$ went to a special school, moving on to a training centre at the age of 16 , which he still attends daily, travelling by taxi. His mother thinks highly of the centre; though he has not been able to learn to do anything, $X$ has made a small social advance and his daily absence allows Mrs. M. N. to work in the shop. The money she earns is welcome, but the opportunity to get outside the home and meet ordinary people is even more valuable to her.

\section{Tolerant Community}

This is the story of love and devotion to duty, continued with no break over such a long time as to make it almost heroic. Undoubtedly $\mathrm{X}$ could not have been better looked after-he is well groomed, happy, and in good physical trim. Mrs. M. N. feels, and says, she is lucky; she sees children in wheelchairs, or who are blind or dumb, and is thankful that her son can walk, see, and hear. She is fortunate that she lives in a rural community, stable and tolerant. If $\mathrm{X}$ is brought home early his grandfather, who lives across the street, will let him in and the neighbours are kindly and helpful. She depends a lot on the training centre and hopes $\mathrm{X}$ can stay there indefinitely, saying, "Some of the children there must be 30 years old." The centre does not close for a long summer holiday like the schools do.

Mrs. M. N. tells her story simply and with a smile, but as she gains confidence in her listener emotion begins to appear, tears come to her eyes, and she voices the suppressed and baseless guilt that so many parents of handicapped children experience. She asks, "What can I have done to descrve this?" She and her husband often talk together in the evenings of what the future may hold for the family. $\mathrm{X}$ is far bigger than either of his parents and though he is usually docile sometimes he throws his toys in fits of temper. He has no real ill will but could be rough through heedlessness, and if anything happened to one of the parents the other would not be able to cope alone. $X$ would have to go into an institution, and understandably his parents' hearts sink at the thought.

\section{Information Withheld}

Articulate women who are the mothers of mentally subnormal children often complain of the difficulty they experience in the early days in getting any information about the nature of the condition from which their child is suffering, what the cause is, and what the parents can expect in the way of development in the future. Many say that information is never volunteered; they themselves suspect something is wrong, sometimes for long periods, before anyone will confirm their fears. Doubtless it may be felt that if the woman is allowed gradually to realize that all is not well she will have accepted in her heart that the child is subnormal or handicapped, and that the shock when the diagnosis is made will not be so great. Most women reject this theory, saying that the worst time of their lives was when they feared something was wrong but did not dare to ask, or were given kindly but vague suggestions of backwardness when they longed for hard facts. The mother bears the principal burden since it is she who takes the baby round the hospitals and specialists, often seeing someone different each time she goes to hospital. Many women say that telling their husband the verdict was the worst part and wish that both of them could be told together. If the family doctor breaks the news this is comparatively easy to arrange. What can always be attempted is to remove the burden of guilt that is almost always felt by these women, even if this is not overtly expressed, and this can be done only in the earliest stages. One feels that this couple would not be forgotten today in the way that they were nearly a quarter of a century ago, and that they would be encouraged as well as enabled to take a holiday together.

\section{Mental Health Services}

Before the last Government fell the Department of Health and Social Services had undertaken an investigation into psychiatric and mental subnormality hospitals and services. The advent of a new Government meant that this material was never made public and this is to be regretted, since, even if the present Government did not accept the conclusions, the contents would have been of great interest to all concerned with mental health services. 